tion, the Belgian organisation, the Union Minière du Haut-Katanga, offered the loan of five grams of radium for two years free of cost except for insurance, with an additional five grams at a later date if considered necessary. An executive research committee has been formed with Prof. J. C. McLennan as chairman. The place for the research is the London Radium Institute, Ridinghouse Street, Portland Place, London, W.1, which has generously placed the whole of the accommodation necessary at the disposal of the governing body.

\section{Alcoholism in Medieval England}

Ат a meeting of the Society for the Study of Inebriety and Drug Addiction on July 11, a paper on alcoholism in medieval England was read by Dr. J. D. Rolleston, who said that the chief sources of information concerning the prevalence of alcoholism in the Middle Ages were lay writers, especially poets, historians and ecclesiastics, whereas little was to be gleaned from contemporary medical works. In the Middle Ages, distilled liquors were unknown as a convivial beverage and alcoholism was due mainly to indulgence in ale and to a less extent in wine. Inebriety was widely spread in all classes of society, but predominated among the clergy, in spite of the protests of leading ecclesiastics such as Anselm, Bede, Boniface, Dunstan and Wycliffe, and among the university students. The medieval publican had a bad reputation for fraud and dishonesty, while the tavern was often regarded as a place of ill-repute. Alcoholism during the Middle Ages in England, as elsewhere, resembled in many ways the alcoholism of classical antiquity, which Dr. Rolleston discussed in a previous paper before the Society (see NaturE, Oct. 23, 1926, p. 601). Legislation dealing with drunkenness or control of the liquor trade was practically unknown in the ancient world, whereas taxation of drink, reduction in the hours of sale and the number of taverns and other restrictions were introduced in the Middle Ages. The absence of syphilis in both ages was noteworthy in view of the fact that alcohol was such a frequent incentive to exposure to infection and was liable to aggravate the disease when once it was acquired.

\section{Atmospheric Pollution in Great Britain}

IN a paper read before the National Smoke Abatement Society on July 14, Sir Frank Baines, the well-known architect, dealt at some length with the effects of atmospheric pollution on buildings, vegetation and public health. While he was Director of Works and Buildings at H.M. Office of Works, Sir Frank had exceptional opportunities for studying the effects on national buildings of the various impurities in the atmosphere due to the burning of coal, and for estimating what it costs the nation in deterioration of buildings and repairs due to this cause alone. $\mathrm{He}$ gave this cost for the last twentyfive years as a minimum of 55 million pounds sterling, and contrasted this with the niggardly parsimony of H.M. Treasury in its provision of funds for the investigation of the problem and the institution of methods of prevention. All legislation hitherto devised to cope with the contamination of the atmosphere has failed to deal with sulphur gases, the greatest destructive agents of all. To these agents Sir Frank attributed the rapid deterioration of the stonework of the Houses of Parliament, Westminster Abbey and other great national buildings. Sedimentary stones are peculiarly subject to the attack of atmospherie sulphuric acid formed by the action of moisture on sulphur effluents : but even the surface of granite in buildings is completely destroyed by this acid. Bricks, cement, lime mortars, metal, paints and composite materials of all kinds, vary in susceptibility to this attack, but the general effect is to make it probable that the readings of history in all our national monuments will be rendered unintelligible. The mass of evidence collected by Sir Frank Baines will be invaluable to the serious student of the problem of atmospheric pollution and it is gratifying to know that the National Smoke Abatement Society proposes to make this important paper available to the public.

\section{Memorials in Westminster Abbey}

JUst after the commemoration on April 22-24 of the centenary of Richard Trevithick, to whom there is a window in Westminster Abbey, Eng.-Capt. E. C. Smith, in a letter published in the Times of April 29, directed attention to the removal some time ago, from the north aisle, of three memorial windows, to Joseph Locke, Robert Stephenson and Sir William Siemens respectively. It came as a surprise to many unfamiliar with the memorials in the Abbey to learn that these three windows were no longer in place and further correspondence on the matter has since appeared in Engineering. It is known that it is a good many years since the windows were removed to make way for others, and in a letter in Engineering of July 7 , the Dean of Westminster, the Rev. W. Foxley Norris, writes: "The windows in question were removed before my time and $I$ know nothing of the circumstances, and we are at this moment taking the necessary measures for their replacement, which was, I understand, intended by my predecessor." As the windows to Locke, Stephenson and Siemens were erected mainly through the efforts of contemporary engineers and men of science, in recognition of their high professional standing, it is most desirable from every point of view that the windows should be re-erected, and we trust the Dean and Chapter will be able to find a reasonable solution of the problem with which they are faced

\section{Thermal Convection Air Currents and Gliding}

THE recent spell of hot sunny weather in England made possible a series of experiments concerning the existence and magnitude of thermal convection currents in the air, arising from the reflection of heat from the sun-baked earth. Mr. G. E. Collins, instructor at the British Gliding Association's Summer School at Huish Hill, near Marlborough, using a two-seater glider of the B.A.C.VII type, was towed 
up to $500 \mathrm{ft}$. height, and then succeeded in soaring up to a height of 2,150 ft. He remained in the air for 27 minutes and travelled about 10 miles altogether. Upon another occasion he ascended with a passenger, and reached a height of $1,300 \mathrm{ft}$. under very similar conditions. These are the first properly observed and recorded flights of any magnitude made in Great Britain under meteorological conditions in which there were probably no vertical air currents other than those set up by thermal convection. There were no cumulus clouds to produce the normal up currents beneath them, and there was practically no wind from which energy for soaring might have been derived. It is fair to assume that the lift necessary to raise the machine to these heights was obtained principally from currents of air rising from the heated earth. Knowing the aerodynamic characteristics of the machine, and having observed the speeds and rates of climb during such a flight, it should be possible to make fairly accurate estimations of the magnitude of these currents. Such data will have their value in meteorological statistical records.

\section{Early Culture in Northern Iraq}

Ar the close of the season's excavations at Arpachiyah, near Nineveh, the results obtained by the joint expedition of the British Museum and the British School of Archæology in Iraq had further justified the selection of this site as a possible source of information relating to the early cultural history of northern Iraq. The report on the work of the latter half of the season in the Times of July 14 opens up an enticing prospect for speculation until further discovery supplies links in the chain which now appears to connect Arpachiyah and Minoan Crete. The outstanding feature in a record of finds, which in other respects is by no means devoid of the element of surprise, is the occurrence of the double axe in the sixth level of occupation, a thousand years before it appears in Crete (where indeed Sir Arthur Evans has regarded it as intrusive from western Asia) and the discovery in the seventh level, immediately below, of beehive structures in clay and stone, similar to the beehive tombs of Crete and Mycenæan Greece. It is scarcely necessary to stress the importance of the first occurrence of such structures in Mesopotamia. These discoveries were made in excavating the summit of the mound to which operations were confined in the latter half of the season. Here no less than ten superimposed village settlements have been brought to light, all belonging to a cattle-keeping agricultural population. It is remarkable that in a community of this character the sixth settlement, nearly $20 \mathrm{ft}$. below the surface of the ground, should have yielded in one dwelling, which had been sacked and burned, a rich treasuretrove of objects, mostly, it would appear, of domestic type, and including magnificent specimens of painted polychrome pottery. The suggestion that this was the home of a vase painter is made more than plausible by the block of red paint found in one of the rooms.

\section{Broxbourne 'Finds' at the British Museum}

A sErres of small temporary exhibitions of special prehistoric material is contemplated by the British Museum, to fill a table-case near the top of the main staircase. Following Mr. J. P. T. Burchell's exhibit of the flint sequence from Swanscombe and Northfleet in Kent is a small collection of flints from Broxbourne, Herts, all from a sealed deposit on the Pleistocene gravel. The discovery was made by $\mathrm{Mr}$. Hazzledine Warren, who is about to publish it in collaboration with Mr. Grahame Clark. The material is sharp and barely patinated, consisting of cores and end-scrapers, large and pygmy gravers, raw material in the form of blades, and two picks, the predecessors of the neolithic axe. The occupation site was covered by peat of the Boreal period, as determined by pollen analysis, and the industry may safely be referred to that cool and dry period. of pine and hazel forest which followed the arctic spell at the close of the Palæolithic. This Boreal period corresponds to the Ancylus stage of the Scandinavian Stone Age, and may be dated about 6000 B.c. This exhibition will continue through July and August, and will be followed by others dealing mainly with the Stone Age of Britain.

\section{Uses of Coal and its Products}

THE appearance of the first half-yearly summary of progress in research and technical development of the utilisation of coal and its by-products, issued by the Utilisation of Coal Committee of the Institute of Mining Engineers, directs attention to the change which adversity has produced in the coal industry. Until recently, it was substantially true to say that the industry was indifferent and left such matters to the consumer. The consumer has, however, reduced his consumption of coal either by greater efficiency, or by the use of substitutes, until the point has been reached when it is seen that coal consumption must be cultivated if coal production is to exist. The Institution is now issuing frequent bulletins which direct attention to new developments and ideas respecting the use of coal and its products. They are interesting and informative documents and reveal a departure from the 'raw coal' mentality which has been an obsession with the coal producer. Coal will only survive in face of competition by the use of methods which are efficient and convenient, and frequently this is not the case with the use of crude lump fuel. The bulletin reports that the outstanding development during the last six months has been in the use of compressed coal-gas for driving public service vehicles. For these engines, coal-gas is an almost ideal fuel, and the disadvantages of com. pressed gas are least felt when the vehicles ply within a limited radius.

\section{Grasshopper Plague in the United States}

According to a Wire Report of Science Service, Washington, D.C., dated June 9, grasshoppers are likely to be a more serious plague in the north- 